Original Research Article

\title{
Perspectives of students in a medical school regarding Hepatitis $B$ and $C$ in North West India
}

\author{
Rajiv Kumar Gupta ${ }^{1 *}$, Parveen Singh ${ }^{1}$, Bhavna Langer ${ }^{1}$, Rashmi Kumari ${ }^{1}$, \\ Najma Akhter ${ }^{1}$, Riya Gupta ${ }^{2}$
}

\begin{abstract}
${ }^{1}$ Department of Community Medicine, Government Medical College, Jammu, J\&K, India ${ }^{2}$ Department of Community Medicine, Acharya Shri Chander College of Medical Sciences \& Hospital, Sidhra, Jammu, J\&K, India
\end{abstract}

Received: 06 October 2017 Accepted: 09 November 2017

\section{*Correspondence to:}

Dr. Rajiv Kumar Gupta, Email: krishna@ hotmail.com

Copyright: (c) the author(s), publisher and licensee Medip Academy. This is an openaccess article distributed under the terms of the Creative Commons Attribution NonCommercial License, which permits unrestricted noncommercial use, distribution, and reproduction in any medium, provided the original work is properly cited.

\begin{abstract}
Background: Hepatitis B and Hepatitis C are among the major public health problems in the world and students in the medical schools as a group is highly vulnerable to these infections. The current study aimed to assess the pers pectives (knowledge, attitude and practices) of these students about both Hepatitis B and Hepatitis C.

Methods: The present cross-sectional study was conducted in a medical school in northwest India using a self administered questionnaire. This study was carried out in the month of July 2017 using a convenience sample of Pre-final MBBS students.

Results: The knowledge of the respondents was found to be good on most of the parameters except for living with Hepatitis $\mathrm{B} / \mathrm{C}$ patient being a risk factor for disease and Hepatitis B being curable. On the same pattern, attitudes were also found to be positive on most of the parameters except willingness to undergo screening for the diseases. Practices of the respondents were also adequate except for use of gloves while examining a patient/collecting blood sample. An important positive practice observed was that $92.8 \%$ of the respondents were protected against Hepatitis B.

Conclusions: The study has concluded that perspective of medical students towards Hepatitis B and Hepatitis C are reasonably good and areas of concem need to be taken care of. Both these diseases remain a challenge for health community in general and medical students in particular due to their being an occupational hazard, so the need for infection control training before they start clinical education is strongly recommended.
\end{abstract}

Keywor ds: Hepatitis B, Hepatitis C, Medical students, Northwest India

\section{INTRODUCTION}

The term "hepatitis" implies injury to the liver by inflammatory cells, a condition caused by numerous origins. All inclusive, most cases of hepatitis are caused by viruses, predominantly the hepatitis $\mathrm{B}$ and $\mathrm{C}$ viruses. Estimated 325 million people are living with chronic hepatitis infections (HBV or HCV) worldwide making Hepatitis a major public health problem across the world. ${ }^{1}$ As per estimates one in twelve people in the world is chronically infected with either Hepatitis B or C. About $78 \%$ of all the primary liver cell carcinoma and $57 \%$ of all cases of liver cirrhosis are due to Hepatitis B and C. ${ }^{2}$ An estimated 257 million people are living with Hepatitis B virus infection (defined as HBs Antigen positive). The range of geographical distribution of Hepatitis B varies from $0.7 \%$ to $6.2 \%$ in different regions of the world depending upon the endemicity of disease. ${ }^{3}$ Globally an estimated 71 million people have chronic Hepatitis C infection. World Health Organization (WHO) estimates reveal its global prevalence varies from $0.5 \%$ to $2.3 \% .^{4}$

Health care workers (HCWs) are at increased risk of exposure to both these diseases especially Hepatitis B. The 
situation is particularly challenging in the developing countries where the prevalence is high in the general population and health care settings are far from satisfactory. Medical students are equally susceptible to risk of $\mathrm{HBV}$ and $\mathrm{HCV}$ due to various factors like lack of experience, insufficient training, duty overload, fatigue etc. 5,6

Both Hepatitis B and C infection can be prevented by adhering to universal precautions like use of gloves, proper sterilization of medical equipment, proper hospital waste management and vaccination. ${ }^{7-9}$ Further post exposure prophylaxis can be used for prevention of $\mathrm{HBV}$ after accidental exposure to contaminated blood or body fluids..$^{8,10}$ Health care personnel, including medical students, should have comprehensive knowledge of viral hepatitis infections, significance of vaccinations and practice of hygienic measure together with specific protective measures.

Knowledge, Attitude and Practices (KAP) study is a useful tool to design public health policies taking into account the awareness, beliefs and health seeking behaviour of the atrisk population. Although some authors have conducted $\mathrm{K}$, $\mathrm{A}$ and $\mathrm{P}$ studies regarding Hepatitis $\mathrm{B}$ among medical students in different parts of India, but the data in our state was rather scarce. Therefore, the present study was conducted with the aim to assess the perspectives (KAP) of the medical students in a medical school in North West India.

\section{METHODS}

The present descriptive cross-sectional study was conducted among Pre-final MBBS students of a Government Medical College in Jammu region of J\&K state, India. The study conducted in the month of July 2017 aimed to assess perspective of undergraduate medical students towards Hepatitis B and Hepatitis C. Due permission was sought from Institutional Ethical Committee before the study was carried out. All the students were briefed about the purpose of the study and confidentiality of the information was ensured. Informed verbal consent was taken from all the respondents.

The data collection tool was a predesigned selfadministered questionnaire. The questionnaire was prepared by the faculty members of Community Medicine and help was sought from faculty of Internal Medicine and Microbiology for its validation. The questionnaire was pretested during a pilot study which was conducted among a group of 25 Final year MBBS students who eventually were not part of the study group. The results of the pre-test were evaluated and some modifications into the final version of the questionnaire were incorporated.

The questionnaire had 29 items grouped into four sections: socio-demographic and history of hepatitis, knowledge, attitude and practice sections.
The data thus collected was tabulated and analysed. Chi square test was conducted to determine the association of independent variables with the outcome variables of interest which included knowledge, attitude and practices related to Hepatitis B and Hepatitis C. P-value $<0.05$ was considered as significant.

\section{RESULTS}

In all, 140 students were administered the questionnaire and majority of them $(52.8 \%)$ were females. Of the total, $51.4 \%$ of the respondents belonged to the Hindu religion and $55.7 \%$ were residing in the urban areas. Regarding history of Hepatitis B infection in the family, only $12.14 \%$ of the respondents replied in the affirmative (Table 1).

Table 1: Demographics including family history of Hepatitis among the respondents $(n=140)$.

\begin{tabular}{|c|c|c|c|}
\hline \multicolumn{2}{|c|}{$\begin{array}{l}\text { Socio demographic } \\
\text { variable }\end{array}$} & \multirow{2}{*}{$\begin{array}{l}\text { Number } \\
21\end{array}$} & \multirow{2}{*}{$\begin{array}{l}\text { Percentage } \\
15.00 \%\end{array}$} \\
\hline \multirow{4}{*}{$\begin{array}{l}\text { Age in } \\
\text { completed } \\
\text { years }\end{array}$} & 21 years & & \\
\hline & 22 years & 90 & $64.29 \%$ \\
\hline & 23 years & 23 & $16.43 \%$ \\
\hline & 24 years & 06 & $4.28 \%$ \\
\hline \multirow{2}{*}{ Gender } & Male & 66 & $47.14 \%$ \\
\hline & Female & 74 & $52.86 \%$ \\
\hline \multirow{4}{*}{ Religion } & Hindu & 72 & $51.43 \%$ \\
\hline & Mus lim & 59 & $42.14 \%$ \\
\hline & Sikh & 07 & $05 \%$ \\
\hline & Others & 02 & $1.43 \%$ \\
\hline \multirow{2}{*}{ Residence } & Urban & 78 & $55.71 \%$ \\
\hline & Rural & 62 & $44.29 \%$ \\
\hline \multirow{2}{*}{$\begin{array}{l}\text { Family income } \\
\text { per month (in } \\
\text { Rupees) }\end{array}$} & $<50000$ & 38 & $27.14 \%$ \\
\hline & $>50000$ & 102 & $72.86 \%$ \\
\hline \multirow[b]{2}{*}{$\begin{array}{l}\text { Have you or } \\
\text { your family } \\
\text { member ever } \\
\text { suffered from } \\
\text { Hepatitis } \\
\text { B/Hepatitis C } \\
\text { infection }\end{array}$} & Yes & 17 & $12.14 \%$ \\
\hline & No & 123 & $87.86 \%$ \\
\hline
\end{tabular}

The results showed that $95 \%$ of the respondents were aware of Hepatitis B vaccine availability. Male students had better knowledge of mode of spread of the disease ( $p$ $<0.05$ ). More male than female students said that living with a Hepatitis B/ Hepatitis C patient was a risk factor ( $p$ $<0.05$ ) while both male and female students had good knowledge regarding the diagnosis of Hepatitis B and Hepatitis C. Both group of students had good knowledge about treatment, post exposure prophylaxis and role of screening of blood transfusion ( $p>0.05$ ). Higher proportion of male students had correct knowledge about Hepatitis B being curable than their female counterparts and this difference was found to be statistically significant $(\mathrm{p}<0.05)$ (Table 2). 
Table 2: Knowledge of the respondents regarding hepatitis $B(n=140)$.

\begin{tabular}{|c|c|c|c|c|c|}
\hline Question & Response & $\begin{array}{l}\text { Males } \\
(\mathrm{n}=66)\end{array}$ & $\begin{array}{l}\text { Females } \\
(\mathrm{n}=\mathbf{7 4})\end{array}$ & $\begin{array}{l}\text { Total } \\
(\mathrm{n}=\mathbf{1 4 0})\end{array}$ & $\begin{array}{l}\mathbf{P} \\
\text { value }\end{array}$ \\
\hline \multirow{2}{*}{ Is hepatitis B vaccine available } & Yes & $65(98.48)$ & 68(91.89) & $133(95.00)$ & \multirow{2}{*}{0.15} \\
\hline & No & $01(1.52)$ & $06(8.10)$ & $07(5.00)$ & \\
\hline \multirow{2}{*}{$\begin{array}{l}\text { Modes of spread of Hepatitis B and Hepatitis C is } \\
\text { blood/sexual contact }\end{array}$} & Yes & $60(90.91)$ & $54(72.97)$ & $114(81.43)$ & \multirow{2}{*}{0.00} \\
\hline & No & 06(9.09) & $20(27.03)$ & $26(18.57)$ & \\
\hline \multirow{2}{*}{ Carriers of hepatitis B can transmit infection } & Yes & 62(93.94) & $55(74.32)$ & $117(83.57)$ & \multirow{2}{*}{0.01} \\
\hline & No & $04(6.06)$ & $19(25.68)$ & $23(16.43)$ & \\
\hline \multirow{2}{*}{$\begin{array}{l}\text { Hepatitis B/ Hepatitis C can be transmitted by } \\
\text { unsterilized syringes, needles and surgical instruments }\end{array}$} & Yes & $61(92.42)$ & $67(90.54)$ & $128(91.43)$ & \multirow{2}{*}{0.69} \\
\hline & No & $05(7.58)$ & $07(9.46)$ & $12(8.57)$ & \\
\hline \multirow{2}{*}{$\begin{array}{l}\text { Living with Hepatitis B / Hepatitis C patient is a risk } \\
\text { factor for the disease }\end{array}$} & Yes & $50(75.76)$ & 27(36.49) & $77(55.00)$ & \multirow{2}{*}{0.00} \\
\hline & No & $16(24.24)$ & $47(63.51)$ & $63(45.00)$ & \\
\hline \multirow{2}{*}{$\begin{array}{l}\text { Medical history and laboratory tests help in the } \\
\text { diagnosis of Hepatitis B/ Hepatitis C }\end{array}$} & Yes & 64(96.97) & $69(93.24)$ & $133(95.00)$ & \multirow{2}{*}{0.54} \\
\hline & No & $02(3.03)$ & $05(6.76)$ & $07(5.00)$ & \\
\hline \multirow{2}{*}{$\begin{array}{l}\text { Treatment of Hepatitis B includes immunotherapy/ } \\
\text { Hepatitis B vaccination }\end{array}$} & Yes & 62(93.94) & $67(90.54)$ & $129(92.14)$ & \multirow{2}{*}{0.45} \\
\hline & No & $04(6.06)$ & $07(9.46)$ & $11(7.86)$ & \\
\hline \multirow{2}{*}{ Post exposure prophylaxis is available in Hepatitis B } & Yes & $56(84.85)$ & $63(85.14)$ & $119(85.00)$ & \multirow{2}{*}{0.96} \\
\hline & No & $10(15.15)$ & 11(14.86) & $21(15.00)$ & \\
\hline \multirow{2}{*}{$\begin{array}{l}\text { Screening of blood transfusion and Hepatitis B } \\
\text { vaccination help in prevention }\end{array}$} & Yes & 63(95.45) & 68(91.89) & 131(93.57) & \multirow{2}{*}{0.61} \\
\hline & No & $03(4.55)$ & $06(8.11)$ & $09(6.43)$ & \\
\hline \multirow{2}{*}{ Hepatitis B can be cured/treated } & Yes & $18(27.27)$ & $35(47.29)$ & $53(37.86)$ & \multirow{2}{*}{0.01} \\
\hline & No & $48(72.73)$ & $39(52.70)$ & $87(62.14)$ & \\
\hline \multirow{2}{*}{ Hepatitis B vaccine is safe for all ages } & Yes & $58(87.88)$ & 63(85.14) & $121(86.43)$ & \multirow{2}{*}{0.63} \\
\hline & No & $08(12.12)$ & 11(14.86) & $19(13.57)$ & \\
\hline
\end{tabular}

Table 3: Attitudes of the respondents regarding hepatitis $B(n=140)$.

\begin{tabular}{|c|c|c|c|c|c|}
\hline Question & Response & $\begin{array}{l}\text { Males } \\
(\mathrm{n}=66)\end{array}$ & $\begin{array}{l}\text { Females } \\
(\mathrm{n}=74)\end{array}$ & $\begin{array}{l}\text { Total } \\
(\mathrm{n}=140)\end{array}$ & P value \\
\hline \multirow{2}{*}{$\begin{array}{l}\text { Willingness to get screened for Hepatitis B } \\
\text { and Hepatitis C }\end{array}$} & Yes & $36(54.55)$ & $60(81.08)$ & $96(68.57)$ & \multirow{2}{*}{0.00} \\
\hline & No & $30(45.45)$ & 14(18.92) & $44(31.43)$ & \\
\hline \multirow{2}{*}{$\begin{array}{l}\text { Do you accept Hepatitis B/ Hepatitis C } \\
\text { infected students in your class }\end{array}$} & Yes & $43(65.15)$ & $63(85.14)$ & $106(75.71)$ & \multirow{2}{*}{0.00} \\
\hline & No & 23(34.85) & 11(14.86) & $34(24.29)$ & \\
\hline \multirow{2}{*}{$\begin{array}{l}\text { I have concern in shaking hands/hugging a } \\
\text { person infected with Hepatitis B/ Hepatitis C }\end{array}$} & Yes & 46(69.69) & $65(87.84)$ & 111(79.29) & \multirow{2}{*}{0.00} \\
\hline & No & $20(30.31)$ & $09(12.16)$ & $29(20.71)$ & \\
\hline \multirow{2}{*}{$\begin{array}{l}\text { I wouldn't mind sharing shaving blades/tooth } \\
\text { brushes with others }\end{array}$} & Yes & $06(9.09)$ & $08(10.81)$ & $14(10.00)$ & \multirow{2}{*}{0.73} \\
\hline & No & $60(90.91)$ & $66(89.19)$ & $126(90.00)$ & \\
\hline \multirow{2}{*}{$\begin{array}{l}\text { Should Hepatitis C patient be vaccinated for } \\
\text { Hepatitis B }\end{array}$} & Yes & $59(89.39)$ & $65(87.84)$ & $124(88.57)$ & \multirow{2}{*}{0.77} \\
\hline & No & $07(10.61)$ & $09(12.16)$ & $16(11.43)$ & \\
\hline \multirow{2}{*}{$\begin{array}{l}\text { Should all health care workers receive } \\
\text { Hepatitis B vaccination }\end{array}$} & Yes & $63(95.45)$ & $70(94.59)$ & $133(95.00)$ & \multirow{2}{*}{0.99} \\
\hline & No & $03(4.55)$ & $04(5.41)$ & $07(5.00)$ & \\
\hline
\end{tabular}

Attitude results revealed that higher proportion of female students were willing to undergo screening for Hepatitis B/ Hepatitis C, accept Hepatitis B/ Hepatitis C infected students in the class and had no concern in shaking hand with a person infected with Hepatitis B/ Hepatitis C $(\mathrm{p}<0.05)$. Among other attitudes like sharing of blades/tooth brushes, vaccination of Hepatitis C patients with Hepatitis $\mathrm{B}$ and all health care workers receiving Hepatitis B vaccine were found to be positive in equal proportion in both the sexes ( $p>0.05$ ) (Table 3$)$.
In the practices, the authors found that $92.8 \%$ of the respondents had been protected against Hepatitis B. More females than males had screened themselves for Hepatitis $\mathrm{B} /$ Hepatitis C and used gloves while examining a patient/ blood collection procedure and this difference was found to be statistically significant $(\mathrm{p}<0.05)$. All the students $(100 \%)$ used sterilized syringe when required though a slightly lesser percentage (95\%) requested for new blade/ sterilized instruments on a visit to hair salon. Further it was found that only $86.43 \%$ of the respondents reported on getting a needle stick injury. (Table 4). 
Table 4: Practice of the respondents regarding hepatitis $B(n=140)$.

\begin{tabular}{|c|c|c|c|c|c|}
\hline Question & Response & $\begin{array}{l}\text { Males } \\
(\mathrm{n}=66)\end{array}$ & $\begin{array}{l}\text { Females } \\
(\mathrm{n}=\mathbf{7 4})\end{array}$ & $\begin{array}{l}\text { Total } \\
(\mathrm{n}=\mathbf{1 4 0})\end{array}$ & $P$ value \\
\hline \multirow{2}{*}{$\begin{array}{l}\text { Have you got yourself vaccinated against } \\
\text { Hepatitis B }\end{array}$} & Yes & 62(93.94) & 68(91.89) & 130(92.86) & \multirow{2}{*}{0.89} \\
\hline & No & $04(6.06)$ & $06(8.11)$ & $10(7.14)$ & \\
\hline \multirow{2}{*}{$\begin{array}{l}\text { Have you ever got yourself screened for } \\
\text { Hepatitis B/ Hepatitis C }\end{array}$} & Yes & $03(4.55)$ & 11(14.86) & $14(10.00)$ & \multirow{2}{*}{0.04} \\
\hline & No & 63(95.45) & $63(85.14)$ & $126(90.00)$ & \\
\hline \multirow{2}{*}{$\begin{array}{l}\text { Do you always use sterilized/disposable } \\
\text { syringe when needed }\end{array}$} & Yes & $66(100)$ & $74(100)$ & $140(100.00)$ & \\
\hline & No & $00(0.00)$ & $00(0.00)$ & $00(0.00)$ & \\
\hline \multirow{2}{*}{$\begin{array}{l}\text { Do you always request for new blade/ } \\
\text { sterilization instruments on a visit to hair salon }\end{array}$} & Yes & 63(95.45) & $70(94.59)$ & $133(95.00)$ & \multirow{2}{*}{0.99} \\
\hline & No & $03(4.55)$ & $04(5.41)$ & $7(5.00)$ & \\
\hline \multirow{2}{*}{$\begin{array}{l}\text { Do you always report on getting a needle stick } \\
\text { injury }\end{array}$} & Yes & $56(84.85)$ & $65(87.84)$ & $121(86.43)$ & \multirow{2}{*}{0.60} \\
\hline & No & $10(15.15)$ & $09(12.16)$ & $19(13.57)$ & \\
\hline \multirow{2}{*}{$\begin{array}{l}\text { Do you always use gloves when examining a } \\
\text { patient or blood collecting procedure }\end{array}$} & Yes & $07(10.61)$ & $23(31.08)$ & $30(21.43)$ & \multirow{2}{*}{0.00} \\
\hline & No & $59(89.39)$ & $51(68.92)$ & $110(78.57)$ & \\
\hline
\end{tabular}

\section{DISCUSSION}

Hepatitis B and Hepatitis C are blood borne pathogens which pose a significant occupational hazard to health care workers especially in countries with high prevalence of these diseases. KAP surveys have been succes sfully used to design health intervention methods and public health policies.

Family history of Hepatitis B/ Hepatitis C was reported by $12.14 \%$ of the respondents which concurs with the results while similar reporting was $33.5 \%$ and $6.8 \%$ in the study conducted by author in Egypt and Ahmad A in Malaysia respectively. ${ }^{11-13} 95 \%$ of the respondents were aware about the availability of Hepatitis B vaccine which concurs with the results reported by Hussain FS et al. ${ }^{14}$ Most of the respondents had adequate knowledge about the modes of transmission which was in line of agreement with the results. ${ }^{12,15}$ In contrast to the results of current study, lower knowledge levels. ${ }^{16-18}$ Lower proportion $(45 \%)$ of the students knew that living with the Hepatitis B or Hepatitis $\mathrm{C}$ patient was not a risk factor which was in contrast to result reported by authors. ${ }^{14}$ Most of the respondents knew about treatment, post exposure prophylaxis and screening of blood transfusion which was in accordance. ${ }^{14}$ However in the study it was reported lower levels of knowledge among the respondents on this count. ${ }^{11,12,19}$ Only $37.8 \%$ of the respondents replied that Hepatitis B was curable whereas $75 \%$ respondents said that disease was curable in the study conducted by authors. ${ }^{14}$ Regarding safety of Hepatitis B vaccine for all ages, $86.4 \%$ replied in affirmative while only $63 \%$ replied positive in the study. ${ }^{11}$

Among the positive attitudes reported by the respondents, $95 \%$ of them said that all health care workers should receive Hepatitis $B$ vaccination and all Hepatitis $C$ patients should be vaccinated against Hepatitis $B$. was reported that $66.3 \%$ respondents said that all HCWs be given Hepatitis B vaccination. ${ }^{11}$ in the study it was reported an overwhelming majority (98.5\%) favouring Hepatitis B vaccination for Hepatitis C patients ${ }^{14}$ In the present study, $75 \%$ of the respondents would accept Hepatitis B/Hepatitis $\mathrm{C}$ infected students in the class while a lower rate of $56.5 \%$ was reported by authors in this regard. ${ }^{11}$

Only $20.7 \%$ of the respondents in the current study had no concern in shaking hands/hugging a person infected with Hepatitis B/Hepatitis $\mathrm{C}$ thus reflecting a negative attitude on the part of the respondents. On the other hand, $90 \%$ of the respondents weren't willing to share shaving blades/tooth brushes with others. In the present study, $68.5 \%$ of the respondents were willing to get screened for both the diseases while a higher rate was reported in the study conducted in Egypt. ${ }^{12}$

Among the practices, $92.8 \%$ of the respondents had protected themselves against Hepatitis B. Other studies reported lower rates to the tune of $63 \%, 52.5 \%, 38.1 \%$ and a dismal $4.9 \%$ respectively regarding Hepatitis B vaccination practice..$^{11,13,19}$ Regarding screening for the disease, $10 \%$ of the respondents replied in affirmative which was in concordance. ${ }^{19}$ Majority $(95 \%)$ of the respondents in the present study requested for the new blade/ sterilized instruments on a visit to a hair salon while only $79.5 \%$ of the respondents elicited this practice. ${ }^{12}$ $86.43 \%$ of the res pondents in the current study reported on getting a needle stick injury in contrast to $53.7 \% .{ }^{19}$ All the respondents were using sterilized disposable syringe if needed which was indeed a very healthy practice. However it was reported that $11.4 \%$ of the respondents weren't using sterilized disposable syringes. ${ }^{12}$ Only $21.43 \%$ of the respondents in the present study were using gloves while examining a patient or during blood collection which is not a good practice and this tendency needs to be curbed.

Overall, gender was significantly associated with safer practices towards Hepatitis B and C. Females significantly had higher proportion of safer practices towards the diseases in comparis on to males. It could be due to females being more responsible and cautious in their daily routines 
compared to males. Theses finding are in congruence with those from Malaysia. ${ }^{13}$ The small sample size and the study being conducted in a single medical school is the main limitation of the current study. Also the reported information may have some recall bias and also may not necessarily reflect the actual state of clinical decision among the participants.

\section{CONCLUSION}

The current study revealed that overall knowledge among the medical students was adequate except for a couple of parameters. Overall attitudes among the respondents were found to be reasonably good except for concern in shaking hands/hugging a Hepatitis B/C patient. Similarly, the practices of the respondents were found to be good except for not using gloves on examining a patient. Majority of the respondents $(92.8 \%)$ had protective cover of Hepatitis B vaccination which is highly commendable practice. Authors recommends that besides teaching all the domains of Hepatitis at undergraduate level, internship period should be used to reinforce these things especially inculcating the safe and hygienic practices amongst the future doctors.

\section{Funding: No funding sources}

Conflict of interest: None declared

Ethical approval: The study was approved by the Institutional Ethics Committee

\section{REFERENCES}

1. World health organization. Hepatitis. Available at: http://www.who.int/hepatitis/en/ last Accessed on 10 September 2017.

2. Colvin HM, Mitchell AE. Hepatitis and Liver Cancer: A National Strategy for Prevention and Control of Hepatitis B and C; 2010:1-253. Available at: https://www.cdc.gov/hepatitis/pdfs/iom-

hepatitisandlivercancerreport.pdf Accessed 10 September 2017

3. WHO. Hepatitis B fact sheet Reviewed July 2017. Available at: http://www.who.int/mediacentre/factsheets/fs 204/en/. Accessed 22 September 2017

4. WHO. Heapatitis C fact sheet updated 2017. Available at:

http://www.who.int/mediacentre/factsheets/fs 164/en/. Accessed 22 September 2017

5. Rogers B, Goodno L. Evaluation of interventions to prevent needle stick injuries in health care occupations. Am J Prev Med. 2000;18(4):90-8.

6. Kohn WG, Collins AS, Cleveland JL, Cleveland JL, Harte JA, Eklund KJ, et al. Guidelines for infection control in dental health-care settings. MMWR Recomm Rep. 2003;52(RR-17):1-61.

7. Molinari J. Infection control. Its evolution to the current standard precautions. J Am Dent Assoc. 2003;134(5):569-74.
8. World Health Organization. Health Care Worker health and Safety. Available at: http://www.who.int/occupational_health/activities/3e pidemio.pdf. Accessed 24 September 2017

9. Hutin Y, Hauri A, Chiarello L, Catlin M, Stilwell B, Ghebrehiwet $\mathrm{T}$, et al. Best infection control practices for intradermal, subcutaneous, and intramuscular needle injections. Bull World Health Organ. 2003;7:491-500.

10. Rachiotis G, Goritsas C, Alikakou V, Ferti A, Roumeliotou A. Vaccination against hepatitis B virus in workers of a general hospital in Athens. Med Lav. 2005;96(1):80-6.

11. AH Al-Hazmi. Knowledge, Attitudes, and Practice of Medical Students Regarding Occupational Risks of Hepatitis B Virus in College of Medicine, Aljouf University. Ann Med Health Sci Res. 2015;5(1):13-9.

12. Atlam SA, Elsabagh HM, Shehab NS. Knowledge, attitude and practice of Tanta University medical students towards hepatitis B and C. Int J Res Med Sci. 2016;4:749-56.

13. Ahmad A, Sann LM, Rahman HA. Factors as sociated with knowledge, attitude and practice related to hepatitis $\mathrm{B}$ and $\mathrm{C}$ among international students of University Putra Malaysia. BMC Public Health. 2016;16:611.

14. Hussain SF, Ahmad SR, Muslehuddin OM, Muslehuddin HM. Knowledge, attitude and practice regarding Hepatitis B among medical students. Int J Community Med Public Health. 2016;3:2977-81.

15. Noubiap JJ, Nansseu JR, Kengne KK, Ndoula ST, Agyingi LA. Occupational exposure to blood, hepatitis $\mathrm{B}$ vaccine knowledge and uptake among medical students in Cameroon. BMC Med Educ. 2013; 13:148.

16. Pathoumthonga K, Khampanisonga P, Quetb F, Latthaphasavang V, Souvong V, Buisson Y. Vaccination status, knowledge and awareness towards hepatitis B among students of health professions in Vientiane. Lao PDR. Vaccine. 2014;32:4993-9.

17. Mesfin YM, Kibret KT. Assessment of Knowledge and Practice towards Hepatitis B among Medical and Health Science Students in Haramaya University, Ethiopia. PLoS One. 2013;8(11):e79642.

18. Othman SM, Saleh AM, Shabila NP. Knowledge about hepatitis B infection among medical students in Erbil city, Iraq. Europ Sci J. 2013;3:1857-7881.

19. Abdela A, Woldu B, Haile K, Mathewos B, Deressa T. Assessment of knowledge, attitudes and practices toward prevention of hepatitis B virus infection among students of medicine and health sciences in Northwest Ethiopia. BMC research notes. 2016 Aug;9:410.

Cite this article as: Gupta RK, Singh P, Langer B, Kumari R, Akhter N, Gupta R. Perspectives of students in a medical school regarding Hepatitis $\mathrm{B}$ and $\mathrm{C}$ in North West India. Int $\mathrm{J}$ Basic Clin Pharmacol 2017;6:2889-93. 